University of Nebraska - Lincoln

DigitalCommons@University of Nebraska - Lincoln

2010

Team identification, trust, and conflict: A mediation model

GuoHong (Helen) Han

Youngstown State University

Peter D. Harms

University of Nebraska - Lincoln, pharms@gmail.com

Follow this and additional works at: https://digitalcommons.unl.edu/leadershipfacpub

Part of the Management Sciences and Quantitative Methods Commons

Han, GuoHong (Helen) and Harms, Peter D., "Team identification, trust, and conflict: A mediation model" (2010). Leadership Institute Faculty Publications. 13.

https://digitalcommons.unl.edu/leadershipfacpub/13

This Article is brought to you for free and open access by the Leadership Institute at DigitalCommons@University of Nebraska - Lincoln. It has been accepted for inclusion in Leadership Institute Faculty Publications by an authorized administrator of DigitalCommons@University of Nebraska - Lincoln. 


\title{
Team identification, trust, and conflict: A mediation model
}

\author{
Guohong (Helen) Han \\ Department of Management, Williamson College of Business Administration, \\ Youngstown State University, Youngstown, Ohio, USA
}

\section{P. D. Harms}

Department of Management, University of Nebraska-Lincoln, Lincoln, Nebraska, USA

\begin{abstract}
Purpose - The current study aims to address the relationship between trust, team identification, and team conflict. Specifically, it aims to examine whether trust in peers mediates the relationship between team identification and team conflict.

Design/methodology/approach - This is an empirical paper based on two field studies. In Study 1, 241 employees in a US Fortune 500 company distributed in various and mostly R\&D teams were surveyed. In Study 2,205 employees in a health care organization in the Midwest were surveyed.

Findings - Team identification was related to lower levels of both task conflict and relationship conflict. This relationship, however, is mediated by the employees' trust in their peers.

Research limitations/implications - This finding addresses concerns about the mechanisms by which employee attitudes contribute to work behaviors.

Practical implications - This study highlights the importance of cultivating team members' sense of "we" rather than a sense of "I" in the team context, reinforcing the crucial role of trust in organizational context. Further, by shedding light on the process by which teams come into conflict, our results suggest a means by which managers and organizations can work towards creating optimal levels of conflict in their work teams.

Originality/value - As far as it is known, this is the first field study that has examined the mediating role of trust between team identity and team conflict.
\end{abstract}

Keywords: team working, trust, conflict

Increasing complexity in the modern workplace has coincided with both greater interdependence and specialization of job roles. Consequently, the use of teams and team-based organizations has become increasingly common (Devine et al., 1999). A recent study by the Center for Creative Leadership found that 91 percent of the participants agreed that teams are fundamental to organizational success (Martin and Bal, 2006). Working in teams can produce benefits - such as the added creativity that comes from working with others from diverse backgrounds. However, teams can also embed problems - such as free riding, idea stagnation, and a greatly increased likelihood of conflict with team members that may be potentially detrimental to team effectiveness (Devine et al, 1999; Jehn and Mannix, 2001).

Many studies have documented the association between conflict and its consequences for team performance (e.g. De Dreu and Weingart, 2003; Jehn, 1994, 1995, 1997). However, Mortensen and Hinds (2001) have noted that much of the research 
has mainly investigated diversity as antecedents of conflict (Curşeu and Schruijer, 2007; Greer et al., 2007; Pelled et al., 1999). Namely, if an individual is different from his/her team members in terms of tenure or race, he/she will be more likely to have conflict with others (Pelled et al., 1999). Research into employee attitudes toward teamwork as a possible antecedent of conflict remains largely under-investigated (Kiffin-Peterson and Cordery, 2003). Likewise, Korsgaard et al. (2008) have argued that the majority of research has focused on conflict types rather than on the processes through which group conflict emerges. Consequently, in this study, we will attempt to address this void in the literature by focusing on two attitudinal characteristics of team members - specifically, team identification and trust in peers - and examining the processes that lead to conflict.

Team identity comes from the construct of organizational identity. Identity has several levels - individual-level identity answers the question of "Who am I?" while organizational identity answers the question of "Who are we as a whole?" (Pratt, 1998). Organizational identification is one's perception of belonging to an organization as an organizational member affectively, evaluatively, and cognitively (e.g. Pratt, 1998). Organizational identification has been shown to be positively related to work attitudes and behaviors. A closely related concept, team identification, is the application of social identity theory in the team setting (Ashforth and Male, 1989) and refers to how team members consider team goals as their own and feel "psychologically intertwined with the group's fate" (Mael and Ashforth, 1995, p. 310). Research has shown that team identity is positively related with workplace outcomes, such as team performance (e.g. Lembke and Wilson, 1998), job satisfaction, and employee's organizational citizenship behavior (Van Dick and Wagner, 2002). When team members identify with their teams, they are more likely to exert effort and avoid conflict because the team's success or failure becomes their own personal interest (see Tyler and Blader (2000), for a review). This paper is particularly interested in whether one's perception of team identification can be negatively related with team conflict.

The other variable as a potential antecedent of conflict in this paper is trust in peers. Our motivation to examine this variable is three-fold. First, trust is an important variable in the workplace, and this has been addressed by a great deal of previous research. For instance, Kirkman et al. (2000) found that trust was a primary issue raised in open-ended comments by members of self-managing work teams. Situationally based trust (i.e. whether or not specific co-workers are trusted) is a better determinant of teamwork preferences, in comparison with dispositional trust (Kiffin-Peterson and Cordery, 2003). In the team context, trust has been shown to be a key antecedent of cooperation (Smith et al., 1995). Hence, according to Golembiewski and McConkie (1975), "perhaps there is no single variable which is so thoroughly influences interpersonal and group behavior as does trust" (p. 131).

Second, many researchers (e.g. Ferres et al., 2004) are concerned that the realm of interpersonal trust studies has put too much focus on vertical trust relationships such as those between workers and managers or organizations and their members. Research into trust relationships at the co-worker level, the horizontal direction, has been largely ignored. Ferres et al. (2004) referred to this lack of research as unfortunate, given that investing in social capital requires trust to be developed not only between, but also within organizational levels. To address this gap, this study makes an attempt to examine trust in peers as well as its consequences. 
Third, most previous research on the main effects of trust have focused either on attitude and perception outcomes or behavioral and performance outcomes. A review of this literature revealed that although the effect of trust on workplace attitudes has been fairly consistent and positive, the effects of trust on actual workplace behaviors and performance are weaker and less consistent (Dirks and Ferrin, 2001). One possible explanation for the inconsistency in the effects of trust on performance is that it acts indirectly through group processes (Hwang and Burgers, 1997).

Lawrence (1997) has noted that research which examined the input-output models typically failed to consider possible intervention variables, which she referred to as the "black box." Responding to this need, researchers have made efforts to test the mediating role of trust in the team context. Consistent with Tuckman's (1965) model of small group development, researchers have attempted to address the process by which groups form, establish relationships, and address problems through confrontation and the sharing of ideas. Using 139 student teams, Curşeu and Schruijer (2007) tested a double-mediation model whereby the effects of team diversity on perceived group performance were mediated by trust and then by conflict. Their results demonstrated that the negative effects of diversity on conflict can be partially offset by higher levels of trust. Further, that trust was positively related to group performance, but that this relationship could be partially mediated by intragroup conflict.

In our best knowledge, no study to date has explicitly explored the mediation role of trust between team identification and team conflict. This study attempts to open the black box by proposing a mediation model of trust between employee attitudes and team outcomes. To illustrate, we intend to investigate whether team identification can lead to trust and ultimately less conflict.

We feel it is important to discuss the levels of analysis of the main constructs here. In this study, trust in peers and team identification is treated as an individual-level construct. Although prior research has often approached team identification as a team-level concept, we argue that team identification can be conceptualized at an individual level since it concerns an individual's affection reaction. Gundlach et al. (2006)) defined team identification as "the extent to which an individual team member identifies with a specific organizational team rather than social groups in general" (p. 1608). They also made the argument that team identification should be considered an individual level variable as it represents the extent to which individual team members perceive a sense of belonging with a particular team. Likewise, Leach et al. (2008), in their paper on a multi-component model of in-group identification, submit that one of the five components of group identification is individual self-stereotyping. That is, that a sense of group or team identification is an individualized perception that can shape an individual's worldview and biases. Similar to traits, individually held identity perceptions show high levels of stability over time and are robust predictors of interpersonal outcomes (Wood et al., 2009).

Regarding conflict, Korsgaard et al. (2008) proposed a multilevel model of group conflict and argue that conflict can occur at individual, dyadic, and intragroup levels. They suggested that conflict should be considered "an individuallevel phenomenon, in that the experience of conflict - the perception and affective reaction to incompatibilities - is an intraindividual phenomenon. At the same time, dyadic and intragroup conflicts are social phenomena that are manifested at higher levels of analysis (i.e. the dyad or the group as a whole; e.g. Fink, 1968; 
Jehn and Bendersky, 2003)" (Korsgaard et al., 2008, p. 1224). In response to this, we aim to investigate conflict in two levels (i.e. individual level and team level) based on two empirical studies. Study 1 examines the individual-level antecedents of individual-level conflict. Individual-level conflict here focuses on the individual perception of conflict among him/her in the team. Friedman et al. (2000)) claimed that it is not well understood how an individual's behavior impacts on his/her own perception of conflict. They tested conflict at an individual level and have argued at least partially an individual makes his/her own work environment, and this type of "micro-environment" is shaped by individual behaviors. Study 2 studies the individual antecedents of group level conflict. Data were measured from supervisor's rating on the team that he/she is supervising as a whole.

Taken together, this paper tries to focus on a cross-level analysis to examine whether an individual's perception of team identification can affect team conflict via the indirect effect of trust.

\section{Conceptual framework and hypotheses}

\section{The link between team identification and trust in peers}

Social identity theory (Tajfel, 1978) and self-categorization theory (Turner, 1982) predict that people are motivated to identify themselves based on membership in social categories or groups for two reasons: self-enhancement (Turner, 1982) and subjective uncertainty reduction (e.g. Hogg and Abrams, 1993). People naturally sort themselves and others into ingroups and outgroups (Ashforth and Male, 1989). Moreover, people also tend to make comparisons between ingroups and outgroups and view ingroup members as more positive (i.e. ingroup favoritism) (Kramer, 1991).

Hogg (2001) noted that the key question for social identity theory is which social identities are more salient in a given context and how they are used for interpretation of perception, thought, and behavior. When a salient team identity exists, individuals are inclined to identify with this identity and are motivated to engage in behaviors that ensure the welfare of their group (Brickson, 2000). Team identification refers to "the process by which individual team members perceive themselves in terms of the values, goals, attitudes, and behaviors they share with other team members" (Janssen and Huang, 2008). Similarly, a sense of team identity means that team members view the rest of team members as in-group members. Failure to do so can result in ingroup-outgroup distinctions within teams, which in turn may lead to reduced team performance (see Williams and O'Reilly, 1998, for a review). For instance, Moore et al. (1999) found that when team identity was lacking, it is very hard for team members to build rapport among each other, which ultimately leads to extreme difficulty in reaching consensus. Research has also shown that employees who identify themselves highly with their group's fates are linked with positive attitudes and consequently work-related outcomes, such as decreased turnover intentions, absenteeism, and increased commitment and citizenship behavior (Chattopadhyay, 1999; Tsui et al., 1992).

Interpersonal trust is defined as "the willingness of a party to be vulnerable to the actions of another party based on the expectation that the other will perform a particular action important to the truster, irrespective of the ability to monitor or control that other party" (Mayer et al, 1995, p. 712). Trust is valued in all areas of business and industry locally and globally as trust proves to be a powerful fac- 
tor in determining how the collaboration works out (Child, 2001). In the teamwork context, trust in peers is defined as "employee's expectations regarding the behavior of their work-group peers so that those who they trust will reliably support processes that help them and oppose processes that will harm them" (Chattopadhyay and George, 2001, p. 782).

Undoubtedly trust is important and highly valued, however, "trust does not come naturally and it has to be carefully structured and managed" (Limerick and Cunnington, 1993, pp. 95-6). Ole Borgen (2001) has even pointed out that "only lip service is paid to the sources of trust and the various mechanisms by which trust is generated in various organizations and in diverse contexts" (p. 209). To address this oversight, Ole Borgen (2001) demonstrated that identification with cooperatives is a significant mechanism for the development of trust.

The present study aims to address and expand on this line of research by investigating the possibility that team identification helps to boost interpersonal trust. Shapiro et al. (1992) hold that one of the three types of trust is identificationbased trust. Further, Lewicki and Bunker (1996) discussed three levels of trust, which typically develop successively. The first two levels are called "calculusbased trust" and "knowledge-based trust," in which the parties are transitioning from a fragile state based on deterrence to a more grounded state based on information and predictability. The third and ultimately high level is "identificationbased trust," where the parties come to understand, appreciate, and even share each other's desires and intentions. They suggest that identification-based trust develops as one comes to know and anticipate needs, choices, and preferences of others and to share some of those same needs, choices, and preferences. Heightened levels of identification enable individuals to think, feel, and respond like the other. Indeed, individuals may incorporate parts of the other into their own psyche as collective identity develops over time. A recent study has lent support to the stage-wise trust development (McAllister et al., 2006).

Along the same line, Kramer (1993) and Kramer and Brewer (1986) argued that team identification develops along with group-based trust and is closely associated with team membership. When employees identify with their team, they see the team's goal as their own and would make increased efforts to achieve that goal. With this in mind, team members will go beyond their role definitions and consider their role in broader team situations. They will be more likely to exchange information and knowledge openly and freely and help each other out in order to advance toward the team goal. The open communication and frequent interactions among team members foster trust within the group (Mishra and Morrissey, 1990). This association between communication and trust has been supported in previous literature (e.g. Gilbert and Tang, 1998).

Moreover, Wann (2006) proposed a team identification-social psychological health model. In his perspective, team identification will result in social connections with others and ultimately enhanced social psychological health. Trust in others is a component of the social acceptance dimension of social well being (Keyes, 1998). After surveying 127 university students, Wann and Polk (2007) found a significant correlation between identification with a local collegiate basketball team and belief in the trustworthiness of others.

Based on the previous argument, it is hypothesized that:

HI. Team identification is positively related to feelings of trust in peers. 


\section{The link between trust in peers and conflict}

Research on conflict has indicated that there are two primary types: relationship conflict and task conflict (Jehn, 1994). Moreover, it has been argued that relationship and task conflict have different effects on group performance outcomes (Greer et al., 2007). According to Jehn (1995), relationship conflict refers to interpersonal disagreements manifested in tension, annoyance, and animosity among group members. Task conflict refers to incompatible views, ideas, and opinions among group members about the content of their decisions.

Substantial literature has agreed that relationship conflict is detrimental to group performance (Amason, 1996; Curşeu and Schruijer, 2007; De Dreu and Weingart, 2003; Greer et al., 2007; Pelled, 1996; Thatcher et al., 2003). Peterson and Behfar (2003) have argued that relationship conflict negatively affects group performance in three primary ways. First, relationship conflict may divert group members' attention away from the shared group problem to one other. The resulting inattention or reduced focus greatly reduces member's information processing (e.g. Jehn and Mannix, 2001). Second, relationship conflicts can lead to increased stress and anxiety (Jehn and Mannix, 2001). This may ultimately limit group members' cognitive functioning. Third, relationship conflict can create interpersonal hostility and result in conflict escalation (e.g. Janssen et al, 1999) through the promotion of aggressive attributions of other group members' behaviors.

Unlike the consistent negative effects found for relationship conflict, current research has shown mixed results for the effects of task conflict on performance. For instance, it has found that task conflict can lead to increased satisfaction with the group decision and a desire to stay in the group as team members might be more likely to voice their own opinions when task conflict occurs (Amason, 1996). A candid discussion to approach conflict can be beneficial while avoiding conflict is ineffective (Barker et al, 1988). Besides, positive conflict values have been found to contribute to strong team relationships that in turn promote team effectiveness and employee organizational citizenship behavior (De Dreu and Van de Vliert, 1997). Corroborating this research, it was found that even in collectivistic cultures, where interdependence and harmonious relationships are highly valued, positive conflict attitudes could shape team effectiveness and drive organizational citizenship (Tjosvold et al, 2003). Likewise, Matsuo (2006) found that task conflict was positively related to innovation in Japanese sales departments. In addition to this, Tjosvold (2008) concluded that conflict can lead to a variety of diverse positive outcomes, including cost-effectiveness and quality improvement (e.g. Tjosvold, 1998), and networks strength contributing to business development (e.g. Tjosvold and Weicker, 1993), to name just a few.

Despite a good deal of literature indicating that task conflict is constructive while relationship conflict is destructive, empirical evidence has painted a somewhat negative picture of the overall effect of both task and relationship conflict on performance (De Dreu and Weingart, 2003; Ilgen et al., 2005). In a meta-analysis of 28 studies, De Dreu and Weingart (2003) revealed that both task conflict and relationship have strong and negative correlations with team performance and team member satisfaction. Jehn (1997) also noted that although moderate task conflict is often linked with positive performance, high levels of task conflict has been noted to be detrimental to members' satisfaction and team performance. In addition, Garcia-Prieto et al. (2003) have noted that increasing attention has been devoted to the interactive and dynamic nature of these two kinds of con- 
flicts. Namely, that task conflict could turn into relationship conflict at some point or vice versa (e.g. Eisenhardt et al., 1997; Jehn and Mannix, 2001). Along the same line of research, across 11 studies, Simons and Peterson (2000) found a mean correlation between the two constructs of 0.47 . Because of this, in the present paper, we argue that both task conflict and relationship conflict have unfavorable consequences for teams.

Just as team identification has been closely linked with trust, so too has trust been closely linked with both task and relationship conflict (Curşeu and Schruijer, 2007; Greer et al., 2007). Previous research has established that in close relationships (high levels of trust) individuals are more likely to avoid conflict or make sure that they do not arise (Coser, 1956; Zaheer et al, 1998). When interpersonal trust is high, individuals are likely to "give the counterpart the benefit of doubt rather than jumping to conclusions about the other's motives and intentions" (Zaheer et al, 1998). Further, according to the definition of trust (Mayer et al., 1995), the predictability inherent in high levels of interpersonal trust is likely to be related with low levels of conflict in which unpredictability plays a big role.

One mechanism for neutralizing conflict is through transparency in communication. O'Reilly (1978) has argued that trust relates to openness and accuracy in communication and group members who trust each other know that group members will provide them accurate, reliable, and complete information (Mishra, 1996). Consequently, members who trust one another are more willing to incur the risk of addressing potential issues in order to resolve conflicts in the open before negative effects emerge. Moreover, if group members trust one another, they should be more likely to accept open disagreements and less likely to infer hidden agendas when task conflict behaviors occur (Mishra, 1996). However, when group members lack trust in one another, they are prone to interpreting ambiguous behaviors in others negatively and likely to infer that relationship conflict is a possible reason for the behaviors (Simons and Peterson, 2000).

Additionally, Jones and George (1998) argue that emotions and moods play a fundamental role in one's experience of trust owing to the reasons that trust embodies affect which may influence one's judgment of the target's trustworthiness. Further, that trust is built on expectations, which can be broken and in turn lead to negative emotions (Jones and George, 1998). Emotion has been recognized as a key dimension of conflict (Pinkley, 1990). Particularly, negative emotion is considered as one of the three properties of conflict situations (Barki and Hartwick, 2004). The negative association between trust and conflict has been supported by empirical evidence. Shrum et al. (2001) examined 53 collaborations in physics and related sciences and found that trust was inversely associated with conflict. Another study (Massey and Dawes, 2007) based on data in 53 firms in Australia found that trust was negatively related with the dysfunctional interpersonal conflict between marketing and sales managers. Likewise, Porter and Lilly (1996) found that trust reduced work-related conflict in the project teams. Finally, Greer et al. (2007) demonstrated that intragroup trust was negatively associated with both task and relationship conflict which then mediated the impact of trust on performance.

Consequently, we predict that:

$H 2 a$. Trust is negatively related with task conflict.

$H 2 b$. Trust is negatively related with relationship conflict. 


\section{Mediating role of trust between team identification and conflict}

Prior research has shown that a strong team identity plays an essential role for optimal team performance in the sense of motivating teamwork and attaining successful team performance (Lembke and Wilson, 1998). When team members align with each other in their thoughts, feelings, and actions, they are better at organizing and coordinating behavior (Haslam, 2001) and team performance is likely to be enhanced.

Tyler and Blader's (2003) group engagement models also proposes that group identity affects people's willingness to cooperate. Indeed, prior research has shown that individuals highly identified with their teams are more likely to cooperate with others (Dewitte and De Cremer, 2001). When an individual identifies with his/her team members, he/she will assess that person's both on- and offtask behaviors and actions in a more positive light, leading to both affective and task conflict reductions (Mortensen and Hinds, 2001). Jackson and Smith's (1999) results have demonstrated that group identification is associated with low perceived conflict. On the other hand, when the identity is not shared among team members, individuals will be more likely to work towards their own goals (Gundlach et al, 2006). This may ultimately lead to more conflicts. Mannix et al (2002) argued that a shared social identity in distributed teams could help to deal with conflict effectively. Northcraft and his colleagues have suggested that when team identity is lacking, team members are likely to misinterpret team members' goals and interests as being different rather than congruent (Northcraft et al., 1995). In an effort to study whether team identity can mitigate both task and relationship conflict, Mortensen and Hinds (2001) researched 24 geographically distributed product development teams distributed within five companies and found that shared team identity negatively related to both affective and task conflict. Desivilya and Eizen's study (2005) also presented evidence that team identification is negatively related with destructive intra-group conflict.

As proposed in $H 1$ and $H 2$, the effect of team identity on conflict is linked through team members' trust in each other. Considering this, we hypothesize that:

$H 3 a$. Trust in peers mediates the relationship between team identification and task conflict.

$H 3 b$. Trust in peers mediates the relationship between team identification and relationship conflict.

In a nutshell, the previous hypotheses can be summarized in Figure 1.

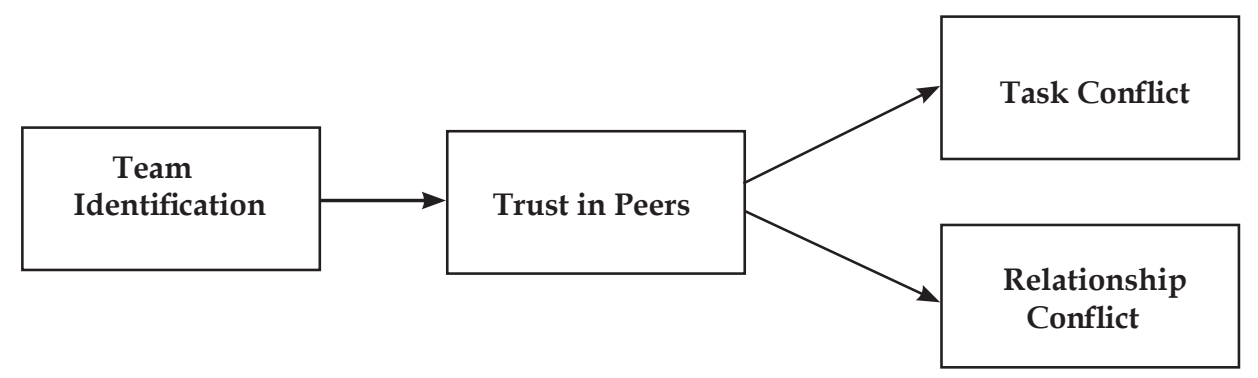

Figure 1. Mediating role of trust between team identity and conflict 


\section{Study 1}

\section{Methods}

Participants and procedures. The organization that is the subject of this research is a Fortune 500 company, famous for producing health and hygiene products. It is well respected in its industry, and its products are highly regarded and extremely competitive on the global market. In fact, it operates in more than 30 countries and sells its products in over 150 markets. In 2005, its sales were valued at nearly \$16 billion.

During the summer of 2006 when the study was conducted, the company was undergoing serious organizational changes. A significant number of people were facing the reality of an upcoming lay-off. This made it very difficult to convince the HR department to distribute the survey company-wide. Fortunately, the study had emphasized the fact that one aim was to promote an understanding of diversity. This attracted the interest of the Diversity department. Taking this into consideration, the department made an effort to accommodate the study.

The company's US operation boasts a workforce of about 8,000 employees and has a presence in two states, one in the mid-west, and the other in the southeast. On approval from the director of the diversity department, the departmental coordinator contacted every diversity network in the company on behalf of the diversity director before sending out the survey via email attachment. The company's US based diversity networks include several minority employee networks, including African American employee, Asian employee, Latin American, Women's network, Gay and Lesbian Employee Network and the like, as well as a few networks that can include any racio-ethnicity, such as new employee network.

To be more specific, the coordinator sent a letter to the chairperson of each network with the survey as an attachment. The letter emphasized that the respondents' inputs were valuable and would be treated with the strictest confidence. In the meantime, the letter highlighted that completed surveys were to be returned to us directly. Employees were not supposed to write their names on the attached questionnaire.

In total, the survey was distributed to eight diversity networks with 2,000 [1] employees who work in various teams. In total, 241 employees completed the survey by sending it directly to the first author as an attachment in their emails. This represented a response rate of 12 percent.

Demographics. At the time of the study, the organization has about 17,000 employees in the USA. In total, 68 percent of them were male and 32 percent were female. White males occupy about 57 percent of the workforce in the USA. Of the respondents, 65 were male ( 27 percent) and 176 were female (73 percent). They had a mean organizational tenure of 9.64 years. Education levels ranged from high school completion to receiving a $\mathrm{PhD}$, with 5.4 percent of the respondents having a high school certificate and the remaining 94.6 percent having college or university education. The mean age was around 36-40 years old.

Respondents came from different teams. Owing to the possibility that some employees can work simultaneously at multiple teams, we requested them to rate themselves on the team that they were currently working most with. Since we were not able to group them into different teams based on their email responses, we were unable to conduct team-level analysis in this study. Respondents occupied diverse occupational levels, ranging from administrative or clerical to upper management. The average reported team size was 15 . 


\section{Measures:}

- Team identification. Following team identity researchers (e.g. Van Der Vegt et al., 2003; Van Der Vegt and Bunderson, 2005), we used the four highest-loading items of affective commitment scale (Allen and Meyer, 1990) to assess team identification. Sample items are "feel emotionally attached to their team," "feel a strong sense of belonging to their team," "feel as if the team's problems are their own," and "feel like part of the family in their team." Items were rated on a five-point scale anchored by $1=$ strongly disagree and $5=$ strongly agree. Cronbach's alpha for this study was 0.87 .

- Trust in peers. We used two items adapted from Jarvenpaa and Leidner's (1999) trust scale to measure trust in peers. "I could rely on those with who I worked on the team" and "Overall, team members are very trustworthy." Items were rated on a five-point scale anchored by $1=$ strongly disagree and $5=$ strongly agree. Cronbach's alpha for this study was 0.89 .

- Task conflict and relationship conflict. We used Jehn's $(1994,1995)$ eight-item conflict scale to measure task conflict and relationship conflict. Four items assessed task conflict $(\mathrm{M}=2.87, \mathrm{SD}=0.66)$ and four items are used to measure relationship conflict $(\mathrm{M}=2.25, \mathrm{SD}=0.75)$. Items were rated on a five-point scale anchored by $1=$ none and $5=a$ lot. A sample item for task conflict is: "How often do the members of your team disagree about how things should be done?" while a sample item for relationship conflict is: "How often do people get angry while working in the team?." Cronbach's alphas in the current study were 0.78 and 0.85 respectively.

\section{Results}

Confirmatory factor analyses. A confirmatory factor analysis of the four key variables (team identification, trust in peers, task conflict, and relationship conflict) was conducted to test their discriminant validity. One-factor, two-factor, threefactor, and four-factor models were conducted respectively. Table I shows the fit indices of each model and the results suggest that the four-factor analysis provides the best fit $(\mathrm{CFI}=0.97, \mathrm{NFI}=0.95, \mathrm{RMSEA}=0.06)$.

Descriptive statistics and correlations. Means, standard deviations, zero-order Pearson correlations, and Cronbach's alphas of all major variables in this study are presented in Table II. Trust in peers, team identification, task conflict, and relationship conflict, were all significantly correlated with each other.

Tests of the hypotheses - tests of the mediation. James et al. (2006) noted that there are currently two prominent approaches in the psychological research literature to test for the mediation effects: the structural equation modeling (SEM) approach and the Baron and Kenny (1986) approach. They assert that Baron and Kenny's

Table I. Confirmatory factor analysis

\begin{tabular}{llllllllr}
\hline Factor & Chi-square/df & RMSEA & NFI & CFI & RMR & GFI & AGFI & PGFI \\
\hline 1 & 9.32 & 0.21 & 0.75 & 0.77 & 0.17 & 0.64 & 0.52 & 0.47 \\
2 & 5.61 & 0.14 & 0.85 & 0.87 & 0.12 & 0.79 & 0.71 & 0.57 \\
3 & 4.01 & 0.12 & 0.9 & 0.92 & 0.08 & 0.84 & 0.78 & 0.59 \\
4 & 2.05 & 0.062 & 0.95 & 0.97 & 0.07 & 0.93 & 0.89 & 0.63 \\
\hline
\end{tabular}


(1986) approach is a partial mediation model where independent variable can affect the dependent variable directly as well as indirectly via the mediator while SEM approach is a full mediation approach in which the independent variable is not necessarily significantly related with the dependent variable, meaning the independent variable can only impact the dependent variable through the mediator. James et al. (2006) indicated that the general strategy for testing for mediation is to determine whether the hypothesized mediation relationship is complete or partial. In this paper, we used SEM to test the mediation.

SEM approach. We used AMOS (Arbuckle, 1997) SEM program to test whether there is a full mediation model by following the three steps pointed out by James et al. (2006):

(1) The link between the IV (independent variable) and $M$ (mediator) is significant.

(2) The link between M and DV (dependent variable) is significant.

(3) There is no significant difference between the observed previous two coefficients correlation and the reproduced correlation of the previous two coefficients.

As Figures 2 and 3 demonstrate, the first two conditions set by James et al. (2006) for full mediation were met for models predicting both task and relationship conflict. For task conflict, team identification was significantly related to trust in peers $(\beta=0.57, p<0.001)$, trust in peers was significantly related to task conflict $(\beta=-$ $0.31, p<0.001)$. Regarding the third condition, we conducted a $t$-test of dependent correlations (Steiger, 1980) and found that the observed relationship ( $r=-$ $0.19, p<0.05)$ between team identification and task conflict was not significantly different $(t=0.38, p=0.70)$ than the reproduced indirect effect $(\beta=-0.18)$. These results offered support for $H 1, H 2 a$, and $H 3 a$.

Likewise, for relationship conflict, team identification was significantly related to trust in peers $(\beta=0.57, p<0.001)$, trust in peers was significantly related to relationship conflict $(\beta=-0.58, p<0.01)$, and the observed relationship $(r=-0.29, p$ $<0.05)$ between team identification and relationship conflict was not significantly different $(t=-1.18, p=0.24)$ than the reproduced indirect effect $(\beta=-0.33)$. These results offered support for $H 1, H 2 b$, and $H 3 b$.

The results of study 1 generally supported the proposed mediated model. At an individual level, the more that an individual identified with their team, the more trust he/she showed in his/her peers. As a consequence of that elevated trust, individuals were less likely to perceive task or relationship conflict in their job site.

Table II. Descriptive statistics and correlations among the key variables in the study

\begin{tabular}{lcccccc}
\hline Variable & Mean & SD & 1 & 2 & 3 & 4 \\
\hline 1. Team identification & 3.48 & 0.93 & $(0.87)$ & & & \\
2. Trust in peers & 3.91 & 0.95 & $0.57^{*}$ & $(0.89)$ & & \\
3. Task conflict & 2.87 & 0.66 & $-0.19^{*}$ & $-0.31^{*}$ & $(0.78)$ & \\
4. Relationship conflict & 2.25 & 0.75 & $-0.29^{*}$ & $0.58^{*}$ & $0.55^{*}$ & $(0.85)$ \\
\hline
\end{tabular}

$n=241 ;$ alpha reliabilities are given in parentheses.

${ }^{*}$ Correlation is significant at the 0.05 level (two-tailed) 


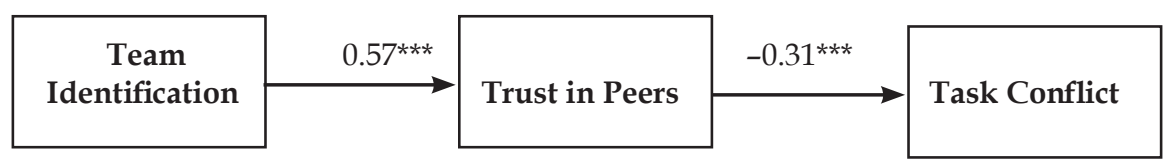

(a)

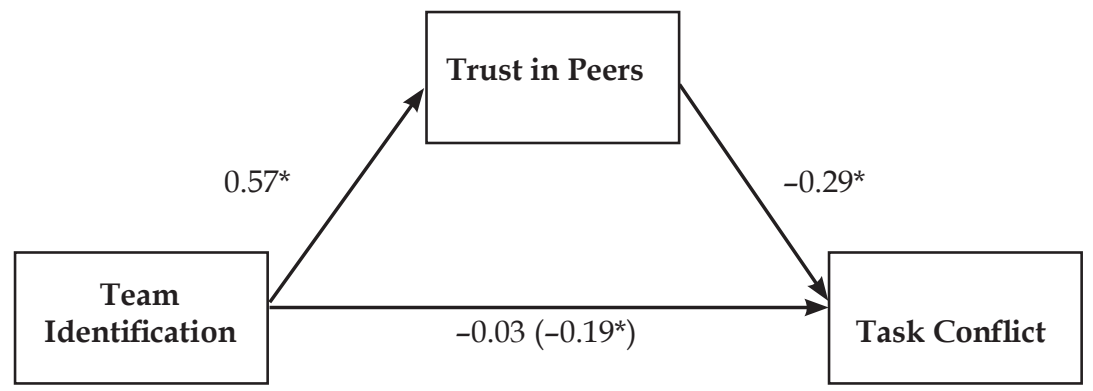

(b)

${ }^{*} p<0.05 ;{ }^{* *} p<0.01 ; * * * 0<0.001$

(a) Fit indexes were: Chi-square $=0.15, \mathrm{df}=1, \mathrm{CFI}=1.00, \mathrm{RMSEA}=0.00$.

(b) The correlation in parenthesis indicates the observed correlation.

Figure 2. Structural model results for task conflict

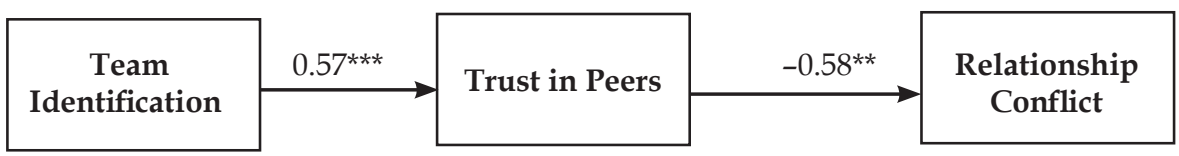

(a)

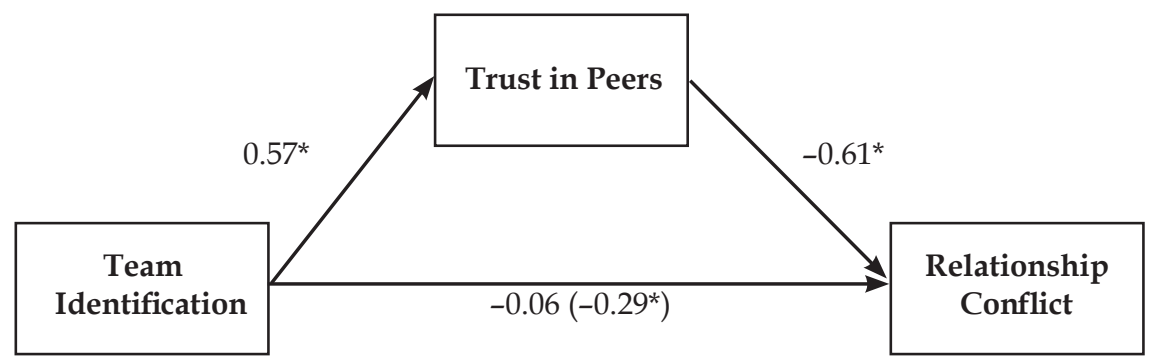

(b)

${ }^{*} p<0.05 ;{ }^{* *} p<0.01 ;{ }^{* * *} p<0.001$
(a) Fit indexes were: Chi-square $=0.78, \mathrm{df}=1, \mathrm{CFI}=1.00, \mathrm{RMSEA}=0.00$.
(b) The correlation in parenthesis indicates the observed correlation.

Figure 3. Structural model results for relationship conflict 


\section{Study 2}

Facing with the limitations of study 1 with low response rate and individual level construct, we explored study 2 to increase the validity of study 1 by replicating the findings of study 1 and exploiting better measures of our major constructs.

\section{Methods}

Procedures and participants. The studied organization is a region of Catholic Healthcare Partners, the largest health system in a mid-western state and one of the largest not-for-profit health systems in the USA. The organization serves the community through several acute care hospitals and a few long-term care campuses that offer a range of services from skilled nursing to independent living. During the period of August to October 2008, we collected data from several units of the organization. The vice president (VP) of the human resources contacted the supervisor of each unit before we started the data collection process. On our request, the VP director picked half of the units that were having high turnover and half of them that were doing relatively well. Units included ortho-trauma, emergency room, long-term care, assisted living, intermediate care, and the like.

Nursing staff filled one survey and the supervisor of the unit filled out another survey, which was mainly focused on team-level data. In total, 204 people participated in the study, 197 of them were nurses, nurse aids, or nurse technicians, seven of them were the supervisors of the team/unit. The response rate was 49.2 percent. Among the nursing staff, ten were male ( 9 percent), and 178 were female (81 percent). Average organizational tenure was 6.21 years. About 59 percent of the participants had at least associate degree education. The mean age group was 35-39 years old. 22 percent of them were part-time employees and 78 percent of them were full-time employees. A total of 164 of them were white (85 percent), and 30 (15 percent) of them were either black, Indian, or Hispanic. The average unit size is about 28 .

This dataset differs from study 1 in that task and relationship conflict were collected from supervisor. Hence both types of conflict were collected at team level, which greatly reduced the limitation of study 1.

Measures. Team identification, trust in peers, task conflict and relationship conflict were from the same scales as those used in study 1 :

- Team identification. We used the four highest-loading items of affective commitment scale (Allen and Meyer, 1990) to assess team identity. Cronbach's alpha for this study was 0.92 .

- Trust in peers. We used two items adapted from Jarvenpaa and Leidner's (1999) trust scale to measure trust in peers. Cronbach's alpha for this study was 0.92 .

- Task conflict and relationship conflict. We used Jehn's (1994, 1995) eight-item conflict scale to measure task conflict and relationship conflict. The supervisor from each unit rated the team-level task conflict and relationship conflict. Cronbach's alphas in the current study were 0.78 and 0.74 respectively.

\section{Results}

Confirmatory factor analysis. A confirmatory factor analysis of the two key variables (team identification and trust in peers) was conducted to test their discriminant validity. One-factor and two-factor were conducted respectively. Table III 
shows the fit indices of each model, and the results suggest that the two-factor analysis provides the better fit $(\mathrm{CFI}=0.97, \mathrm{NFI}=0.96$, $\mathrm{RMSEA}=0.14)$.

Descriptive statistics and correlations. Table IV presents the descriptive statistics and correlations among the key variables in the study.

Tests of mediation. As Figures 4 and 5 demonstrate, the first two conditions set by James et al. (2006) for full mediation were met for models predicting both task and relationship conflict. For task conflict, team identification was significantly re-

Table III. Confirmatory factor analysis

\begin{tabular}{lcccccccr}
\hline Factor & Chi-square/df & RMSEA & NFI & CFI & RMR & GFI & AGFI & PGFI \\
\hline 1 & 21.72 & 0.33 & 0.81 & 0.82 & 0.10 & 0.78 & 0.49 & 0.33 \\
2 & 4.63 & 0.14 & 0.96 & 0.97 & 0.05 & 0.93 & 0.82 & 0.36 \\
\hline
\end{tabular}

Table IV. Descriptive statistics and correlations among the key variables in the study

\begin{tabular}{lcccccc}
\hline Variable & Mean & SD & 1 & 2 & 3 & 4 \\
\hline 1. Team identification & 3.83 & 0.92 & $(0.92)$ & & & \\
2. Trust in peers & 3.74 & 1.03 & $0.67^{*}$ & $(0.92)$ & & \\
3. Task conflict & 2.76 & 0.57 & $-0.21^{*}$ & $-0.24^{*}$ & $(0.78)$ & \\
4. Relationship conflict & 2.50 & 0.55 & $-0.17^{*}$ & $-0.21^{*}$ & $0.84^{*}$ & $(0.74)$ \\
\hline
\end{tabular}

$n=197$; alpha reliabilities are given in parentheses.

* Correlation is significant at the 0.05 level (two-tailed)

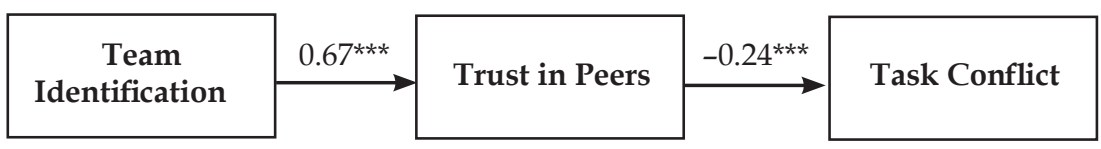

(a)

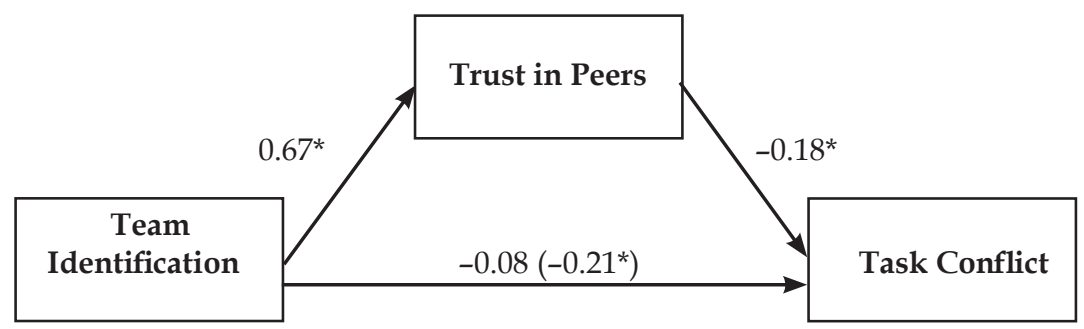

(b)

${ }^{*} p<0.05 ;{ }^{* *} p<0.01 ;{ }^{* * *} p<0.001$

(a) Fit indexes were: Chi-square $=0.79, \mathrm{df}=1, \mathrm{CFI}=1.00, \mathrm{RMSEA}=0.00$.

(b) The correlation in parenthesis indicates the observed correlation.

Figure 4. Structural model results for task conflict 


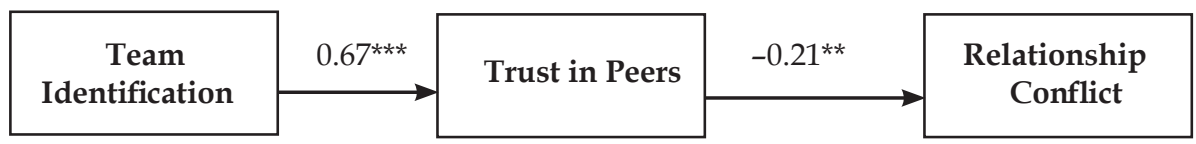

(a)

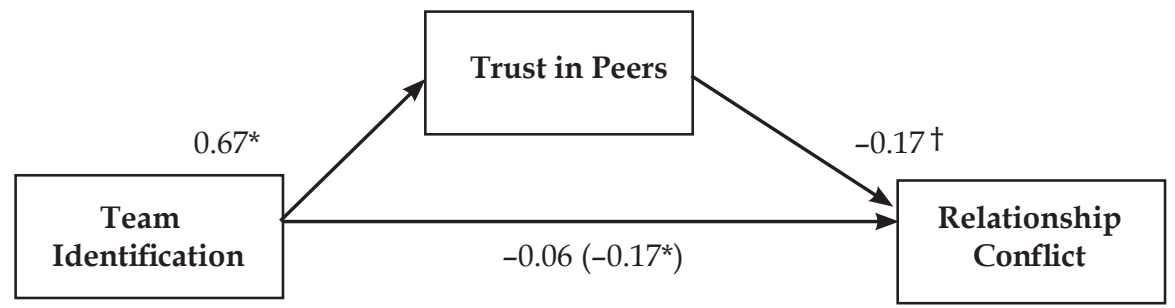

(b)

${ }^{*} p<0.05 ;{ }^{* *} p<0.01 ;{ }^{* * *} p<0.001 ; \dagger p<0.05$ (One tailed test)

(a) Fit indexes were: Chi-square $=0.36, \mathrm{df}=1, \mathrm{CFI}=1.00, \mathrm{RMSEA}=0.00$.

(b) The correlation in parenthesis indicates the observed correlation.

Figure 5. Structural model results for relationship conflict

lated to trust in peers $(\beta=0.67, p<0.001)$, trust in peers was significantly related to task conflict $(\beta=-0.24, p<0.01)$. Regarding the third condition, we conducted a $t$-test of dependent correlations (Steiger, 1980) and found that the observed relationship $(r=-0.21, p<0.05)$ between team identification and task conflict was not significantly different $(t=1.07, p=0.28)$ than the reproduced indirect effect $(\beta=-$ 0.16). These results offered support for $H 1, H 2 a$, and $H 3 a$.

Likewise, for relationship conflict, team identification was significantly related to trust in peers $(\beta=0.67, \mathrm{p}<0.001)$, trust in peers was significantly related to relationship conflict $(\beta=-0.21, p<0.01)$, and the observed relationship $(r=-0.17, p$ $<0.05)$ between team identification and relationship conflict was not significantly different $(t=0.61, p=0.54)$ than the reproduced indirect effect $(\beta=-0.14)$. These results offered support for $H 1, H 2 b$, and $H 3 b$.

The results from study 2 provided additional support for the proposed mediated model. At team level, the more that an individual identified with their team, the more trust he/she showed in his/her peers. As a consequence of that elevated trust, individuals were less likely to perceive task or relationship conflict in their job site.

\section{General findings and discussion}

This paper finds that trust in peers can mediate the relationship between team identification and team conflict. The implications of this paper are multi-fold. 


\section{Theoretical implications}

This study attempts to shed light on several streams of research. It contributes to the literature on the effects of team identification and trust in multiple important ways. First, the link between team identification and conflict (both task conflict and relationship conflict) was examined. As an important determinant of team performance, team conflict has received much attention from team researchers. Current research suggests that a high level of either task or relationship conflict would be detrimental to team performance (e.g. Jehn and Mannix, 2001). Given the pivotal role of conflict, it is important to understand what factors in teamwork might reduce the conflict, which in turn, leads to the increase in team performance. One such factor is team identification. By investigating the link between team identification and conflict, we can better understand the potential antecedents of conflict and be better prepared to prevent conflict from arising. Our results support the negative association between team identity and conflict. This also has implications to organizations.

Second, the mediating role of trust in peers in the relationship between team identity and team conflict was also investigated. After acknowledging team identification as an important antecedent of team conflict, we need to understand also how this process works, or if there is an unopened black box. To the best of our knowledge, this paper is one of the first empirical studies that have tested the relationship between team identification and trust in peers. Our results indicate that team identity can reduce conflict in the workplace through the role of trust in peers. Our results also make contribution to the trust literature by addressing paucity of research on the effects of horizontal trust perceptions on group outcomes.

\section{Practical implications}

This study highlights the importance of cultivating team members' sense of "we" rather than a sense of " $\mathrm{I}$ " in the team context. Training should be provided to team leaders and members, since enhancing team identity can become more challenging nowadays against the background of the current state of the teams. A recent survey of organizations by the Center for Creative Leadership found that approximately 75 percent of work teams are "virtual" in that team members must collaborate across geographic boundaries (Martin and Bal, 2006). Some teams even go further and become global virtual teams. Also, employees are more likely to engage in more than two teams at the same time (Martin and Bal, 2006). Under these circumstances, the question as to the effects of team identity or lack thereof may have major implications for team performance in modern organizations.

This study also reinforced the crucial role of trust in organizational context. Research has shown that trust has two characteristics. On the one hand, it develops slowly in the workplace (Taylor, 1989), and on the other hand, once it was destroyed it is very hard to restore (Fukuyama, 1995). Consequently, it is essential for employees to actively cultivate the trust of their organizational members both in management and in one another.

Further, by shedding light on the process by which teams come into conflict, our results suggest a means by which managers and organizations can work towards creating optimal levels of conflict in their work teams. An abundance of research conducted mainly by Tjosvold (2008) and his colleagues show that con- 
flict, when managed properly, can shape favorable outcomes. It has been noted that while the overall effects of task conflict may be negative, moderate amounts of task conflict are linked with increased group performance (De Dreu, 2006). While the current study does not include group performance as an outcome, the present results suggest that the negative relationship between trust and task conflict may be a mixed blessing. Too little trust may result in overly high levels of task conflict that may spill over into relationship conflict. However, too much trust within a group may result in almost no conflict whatsoever regardless of type. Thus, the group may lose out on the positive effects of task conflict noted in prior research. Our results suggest that fostering employees' trust in one another might ultimately lead to reduced conflict, citizenship behavior, and group performance. They also suggest, further, that the level of group trust could be shaped by manipulating team members' sense of team identification. One possible mechanism for this is to maintain a moderate level of turnover in team membership over time. It could be expected that this would not only increase the adaptive capabilities of the group, but would also reduce the propensity to become complacent. This raises a challenge for team leaders and organizations, which calls for leadership training in these issues.

Notwithstanding, this study is not without limitations. One of the major drawbacks of Study 1 was that we tested all of the variables at the individual level as a consequence of being unable to secure intact team data. This prevented us from conducting team level analysis, which would provide more variance of the data. Data were collected through self-reported surveys at one time, which is liable to common method variance problem (Campbell and Fiske, 1959). In study 2, however, we were able to collect data from specific teams and use multiple sources to assess the variables of interest. In the meantime, we used the supervisor ratings of the team as a whole as team-level conflict scores, rather than the commonly used composition and compilation methods in multilevel research (Hitt et al., 2007). In our opinion, this can better represent the team level conflict than the average score of individual employee rating or the aggregation of individual perception. As our results from study 1 were largely replicated, we can be more confident of our conclusions in spite of these limitations.

Another limitation was that team identification, trust in peers, and conflicts were all measured at a single time point, despite being conceptualized as process variables that develop over time. Consequently, we are unable to conclusively demonstrate the causality of the variables. Prior research has shown that the causal ordering of these variables can be hypothesized to flow in both directions, and that data can be used to support arguments for either direction (Curşeu and Schruijer, 2007). Longitudinal studies may be needed in the future to investigate the development of team identity, trust in peers, conflict, and their relationships.

The present study aimed to open the "black box" of how team identification related to performance outcomes. Specifically, we investigated the role of interpersonal trust as a potential mediator of the relationship between team identity and two types of conflict. Our results broadly confirm an ancient saying by Confucius: "Without trust, we cannot stand." In order to be effective teams must first conceive of themselves as a unit. There must be a "we." Second, the members of that unit must create and maintain a sense of trust within the membership. Fail- 
ure to do so may have far-reaching consequences for not only the team, but the organization itself.

\section{Note}

1. The director of diversity department informed us that only about 30 percent of the 2,000 employees are active members of diversity activities. Consequently, most employees receiving our request for the survey may not have opened the email. Considering this, 12 percent response rate is not as small as it seems.

\section{References}

Allen, N. J. and Meyer, J. P. (1990), “The measurement and antecedents of affective, continuance, and normative commitment to the organization," Journal of Occupational and Organizational Psychology, 63: 18-38.

Amason, A. C. (1996), “Distinguishing the effects of functional and dysfunctional conflict on strategic decision-making: Resolving a paradox for top management teams," Academy of Management Journal, 39: 123-48.

Arbuckle, J. L. (1997), AMOS Users' Guide: Version 3.6, SPSS, Chicago, IL.

Ashforth, B. E. and Male, F. (1989), "Social identity theory and the organization," Academy of Management Review, 14: 20-39.

Barker, J., Tjosvold, D. and Andrews, I. R. (1988), "Conflict approaches of effective and ineffective managers: A field study in a matrix organization," Journal of Management Studies, 25: 167-78.

Baron, R. M. and Kenny, D. A. (1986), “The moderator-mediator variable distinction in social psychological research: Conceptual, strategic, and statistical considerations," Journal of Personality and Social Psychology, 51: 1173-82.

Barki, H. and Hartwick, J. (2004), "Conceptualizing the construct of interpersonal conflict," International Journal of Conflict Management, 15: 216-44.

Brickson, S. (2000), "The impact of identity orientation on individual and organizational outcomes in demographically diverse settings," Academy of Management Review, 25: 82-101.

Campbell, D. T. and Fiske, D. W. (1959), "Convergent and discriminant validation by the multitrait-multimethod matrix," Psychological Bulletin, 56: 81-105.

Chattopadhyay, P. (1999), "Beyond direct and symmetrical effects: The influence of demographic dissimilarity on organizational citizenship behavior," Academy of Management Journal, 4: 273-87.

Chattopadhyay, P. and George, E. (2001), "Examining the effects of work externalization through the lens of social identity theory," Journal of Applied Psychology, 86: 781-8.

Child, J. (2001), "Trust - the fundamental bond in global collaboration," Organizational Dynamics, 29: 274-88.

Coser, L. (1956), The Functions of Social Conflict, The Free Press, New York, NY.

Curşeu, P. and Schruijer, S. (2007), "Does conflict shatter trust or does trust reduce conflict in teams? Revisiting relationships between team diversity, conflict, trust, and team," paper presented at the International Association for Conflict Management Annual Meeting, July 1-4, Budapest. 
De Dreu, C. K. W. (2006), "When too little or too much hurts: Evidence for a curvilinear relationship between task conflict and innovation in teams," Journal of Management, 32: 83-107.

De Dreu, C. K. W. and Van de Vliert, E. (1997), Using Conflict in Organizations, Sage, Beverly Hills, CA.

De Dreu, C. K. W. and Weingart, L. R. (2003), “Task versus relationship conflict, team performance, and team member satisfaction: A meta-analysis," Journal of Applied Psychology, 88: 741-9.

Desivilya, H. S. and Eizen, D. (2005), "Conflict management in work teams: The role of social self-efficacy and group identification," The International Journal of Conflict Management, 16: 183-208.

Devine, D. J., Clayton, L. D., Philips, J. L., Dunford, B. B., and Melner, S. B. (1999), "Teams in organizations," Small Group Research, 30: 678-711.

Dewitte, S. and De Cremer, D. (2001), "Self-control and cooperation: Different concepts, similar decisions? A question of the right perspective," Journal of Psychology, 135: 133-53.

Dirks, K. T. and Ferrin, D. (2001), "The role of trust in organizational settings," Organization Science, 12: 450-67.

Eisenhardt, K. M., Kahwajy, J. L., and Bourgeois, L. J. (1997), “Conflict and strategic choice: How top teams disagree," California Management Review, 39: 43-62.

Ferres, N., Connel, J., and Travaglione, A. (2004), "Co-worker trust as a social catalyst for constructive employee attitudes," Journal of Managerial Psychology, 19: 608-22.

Fink, C. F. (1968), "Some conceptual difficulties in the theory of social conflict," Journal of Conflict Resolution, 12: 412-60.

Friedman, R. A., Tidd, S. T., Currall, S. C., and Tsai, J. C. (2000), "What goes around comes around: The impact of personal conflict style on work conflict and stress," International Journal of Conflict Management, 11:32-55.

Fukuyama, F. (1995), Trust: The Social Virtues and the Creation of prosperity, The Free Press, New York, NY.

Garcia-Prieto, P., Bellard, E., and Schneider, S. C. (2003), “Experiencing diversity, conflict, and emotions in teams," Applied Psychology: An International Review, 52: 413-40.

Gilbert, J. A. and Tang, L. P. T. (1998), “An examination of organizational trust antecedents," Public: Personnel Management, 27: 321-5.

Golembiewski, R. T. and McConkie, M. (1975), "The centrality of interpersonal trust in group processes," in Cooper, C. L. (ed.), Theories of Group Processes, Wiley, New York, NY.

Greer, L., Jehn, K., Thatcher, S., and Mannix, E. (2007), “The effect of trust on conflict and performance in groups split by demographic faultlines," paper presented at the International Association for Conflict Management Annual Meeting, July 1-4, Budapest.

Gundlach, M., Zivnuska, S., and Stoner, J. (2006), "Understanding the relationship between individualism-collectivism and team performance through an integration of social identity theory and the social relations model," Human Relations, 59: 1603-32.

Haslam, S. A. (2001), Psychology in Organizations: The Social Identity Approach, Sage, London. 
Hitt, M. A., Beamish, P. W., Jackson, S. E., and Mathieu, J. E. (2007), “Building theoretical and empirical bridges across levels: Multiple research in management," Academy of Management Journal, 50: 1385-99.

Hogg, M. A. (2001), "A social identity theory of leadership," Personality and Social Psychology Review, 5: 184-200.

Hogg, M. A. and Abrams, D. (1993), "Towards a single-process uncertainty-reduction model of social motivation in groups," in Hogg, M. A. and Abrams, D. (eds.), Group Motivation: Social Psychological Perspectives, Harvester-Wheatsheaf, London: 173-90.

Hwang P. and Burgers, W. (1997), "Properties of trust: An analytic view," Organizational Behavior and Human Decision Processes, 69: 67-73.

Ilgen, D. R., Hollenbeck, J. R., Johnson, M., and Jundt, D. (2005), “Teams in organizations: From input-process-output model to IMOI models," in Fiske, S. T., Kasdin, A. E., and Schacter, D. L. (eds.), Annual Review of Psychology, 56: 517-43.

Jackson, J. W. and Smith, E. R. (1999), "Conceptualizing social identity: a new framework and evidence for the impact of different dimensions," Personality and Social Psychology Bulletin, 25: 120-35.

James, L. R., Mulaik, S. A., and Brett, J. M. (2006), “A tale of two methods," Organizational Research Methods, 9: 233-44.

Janssen, O. and Huang, X. (2008), “Us and me: Team identification and individual differentiation as complementary drivers of team members' citizenship and creative behaviors," Journal of Management, 34: 69-88.

Janssen, O., Van De Vliert, E., and Veenstra, C. (1999), "How task and person conflict shape the role of positive interdependence in management teams," Journal of Management, 25: 117-42.

Jarvenpaa, S. and Leidner, D. (1999), "Communication and trust in global virtual teams," Organization Science, 10: 791-815.

Jehn, K. A. (1994), “Enhancing effectiveness: An investigation of advantages and disadvantages of value-based intragroup conflict," International Journal of Conflict Management, 5: 223-38.

Jehn, K. A. (1995), "A multimethod examination of the benefits and detriments of intragroup conflict," Administrative Science Quarterly, 40: 256-82.

Jehn, K. A. (1997), "A qualitative analysis of conflict types and dimensions in organizational groups," Administrative Science Quarterly, 42: 530-57.

Jehn, K. A. and Bendersky, C. (2003), "Intragroup conflict in organizations: A contingency perspective on the conflict-outcome relationship," Research in Organizational Behavior, 25: 187-243.

Jehn, K. A. and Mannix, E. A. (2001), “The dynamic nature of conflict: A longitudinal study of intragroup conflict and group performance," Academy of Management Journal, 44: 238-51.

Jones, G. R. and George, J. M. (1998), “The experience and evolution of trust: Implications for cooperation and teamwork, Academy of Management Review, 23: 531-46.

Keyes, C. L. M. (1998), "Social well being," Social Psychology Quarterly, 61: 121-40. Kiffin-Peterson, S. A. and Cordery, J. L. (2003), "Trust, individualism and job characteristics as predictors of employee preference for teamwork, International Journal of Human Resource Management, 14: 93-116. 
Kirkman, B. L., Jones, R. G., and Shapiro, D. L. (2000), “Why do employees resists teams? Examining the 'resistance barrier' to work team effectiveness," International Journal of Conflict Management, 11: 74-92.

Korsgaard, M. A., Jeong, S., Mahony, D. M., and Pitaru, A. H. (2008), “A multilevel view of intragroup conflict," Journal of Management, 34: 1222-52.

Kramer, R. M. (1991), "Intergroup relations and organizational dilemmas: The role of categorization processes," Research in Organizational Behavior, 13: 191-228.

Kramer, R. M. (1993), “Cooperation and organizational identification," in Murnighan, K. (ed.), Social Psychology in Organizations: Advances in Theory and Research, Prentice-Hall, Englewood Cliffs, NJ: 244-68.

Kramer, R. and Brewer, M. A. (1986), "Social identity and the emergence of cooperation in resource conservation dilemmas," in Wilke, H., Rutter, C., and Messick, D. M. (eds.), Experimental Studies of Social Dilemmas, Peter Lang, Frankfurt.

Lawrence, B. S. (1997, "The black box of organizational demography," Organizational Science, 8: 1-22.

Leach, C. W., van Zomeren, M., Zebel, S., Vliek, M. L. W., Ouwerkerk, J. W., and Spears, R. (2008), "Group-level self-definition and self-investment: A hierarchical (multicomponent) model of in-group identification," Journal of Personality and Social Psychology, 95: 144-65.

Lembke, S. and Wilson, M. G. (1998), "Putting the 'team' into teamwork: Alternative theoretical contributions for contemporary management practice," Human Relations, 51: 927-44.

Lewicki, R. J. and Bunker, B. B. (1996), "Developing and maintaining trust in work relationships," in Kramer, R. M. and Tyler, T. R. (eds.), Trust in Organizations: Frontiers of Theory and Research, Sage Publications, Thousand Oaks, CA: 114-39.

Limerick, D. and Cunnington, B. (1993), Managing the New Organization, JosseyBass, San Francisco, CA.

McAllister, D. J., Lewicki, R. J., and Chaturvedi, S. (2006), “Trust in developing relationships: from theory to measurement," Academy of Management Best Conference Papers: G1-G6.

Mael, F. A. and Ashforth, B. E. (1995), "Loyal from day one: Biodata, organizational identification, and turnover among newcomers," Personnel Psychology, 48: 309-33.

Mannix, E. A., Griffith, T. L., and Neale, M. A. (2002), "The phenomenology of conflict in virtual work teams," in Hinds, P. J. and Kiesler, S. (eds.), Distributed Work, MIT Press, Cambridge, MA.

Martin, A. and Bal, V. (2006), The State of Teams, CCL Research Report, Center for Creative Leadership, Greensboro, NC.

Massey, G. R. and Dawes, P. L. (2007, "Personal characteristics, trust, conflict, and effectiveness in marketing/sales working relationships," European Journal of Marketing, 41: 1117-45.

Matsuo, M. (2006), "Customer orientation, conflict, and innovativeness in Japanese sales departments," Journal of Business Research, 59: 242-50.

Mayer, R. C., Davis, J. H. and Schoorman, F. D. (1995), "An integrative model of organizational trust," Academy of Management Review, 20: 709-34. 
Mishra, A. K. (1996), "Organizational responses to crisis: The centrality of trust,” in Kramer, R. and Tyler, T. (eds.), Trust in Organizations: Frontiers of Theory and Research, Sage, Thousand Oaks, CA: 261-87.

Mishra, J. and Morrissey, M. A. (1990), "Trust in employee/employer relationships: A survey of West Michigan managers," Public Personnel Management, 19: 443-63.

Moore, D. A., Kurtzberg, T. R., Thompson, L. L., and Morris, M. W. (1999), “Long and short routes to success in electronically mediated negotiations: Group affiliations and good vibrations," Organizational Behavior and Human Decision Processes, 77: 22-43.

Mortensen, M. and Hinds, P. J. (2001), "Conflict and shared identity in geographically distributed teams," International Journal of Conflict Management, 12: 212-38.

Northcraft, G. B., Polzer, J., Neale, M. A., and Kramer, R. M. (1995), “Diversity, social identity, and performance: Emergent social dynamics in cross-functional teams," in Jackson, S. E. and Ruderman, M. N. (eds.), Diversity in Work Teams, American Psychological Association, Washington, DC: 69-96.

O'Reilly, C. A. (1978), “The intentional distortion of information in organizational communication: A laboratory and field investigation," Human Relations, 31: 173-93.

Ole Borgen, S. (2001), "Identification as a trust-generating mechanism in cooperatives," Annals of Public and Cooperative Economics, 72: 209-28.

Pelled, L. H. (1996), "Demographic diversity, conflict, and work group outcomes: An intervening process theory," Organization Science, 7: 615-31.

Pelled, L. H., Eisenhardt, K. M. and Xin, K. R. (1999), "Exploring the black box: An analysis of work group diversity, conflict, and performance," Administrative Science Quarterly, 44: 1-28.

Peterson, R. S. and Behfar, K. J. (2003), “The dynamic relationship between performance feedback, trust, and conflict in groups: A longitudinal study," Organizational Behavior and Human Decision Processes, 92: 102-12.

Pinkley, R. L. (1990), "Dimensions of conflict frame: Disputant interpretations of conflict," Journal of Applied Psychology, 75: 117-26.

Porter, T. and Lilly, B. (1996), "The effects of conflict, trust, and task commitment on project team performance," International Journal of Conflict Management, 7: 361-76.

Pratt, M. G. (1998), “To be or not to be, Central questions in organizational identification," in Whetten, D. and Godfrey, P. (eds.), Identity in Organizations, Developing Theory through Conversations, Sage Publications, Newbury Park, CA: 171-207.

Shapiro, D., Sheppard, B. H., and Cheraskin, L. (1992), "Business on a handshake," Negotiation Journal, 8: 365-77.

Shrum, W., Chompalow, I., and Genuth, J. (2001), "Trust, conflict and performance in scientific collaborations," Social Studies of Science, 31: 681-730.

Simons, T. and Peterson, R. (2000), "Task conflict and relationship conflict in top management teams: The pivotal role of intragroup trust," Journal of Applied Psychology, 85: 102-11.

Smith, K. G., Carroll, S., and Ashford, S. J. (1995), “Intra- and interorganizational cooperation: Toward a research agenda," Academy of Management Journal, 38 : 7-22. 
Steiger, J. H. (1980), “Tests for comparing elements of a correlation matrix," Psychological Bulletin, 87: 245-51.

Tajfel, H. (1978), "Social categorization, social identity and social comparison," in Tajfel, H. (ed.), Differentiation Between Social Groups: Studies in the Social Psychology of Intergroup Relations, Academic Press, London: 61-76.

Taylor, R. G. (1989), "The role of trust in labor-management relations," Organization Development Journal, 1: 85-9.

Thatcher, S., Jehn, K. and Zanutto, E. (2003), "Cracks in diversity research: The effects of diversity fault lines on conflict and performance," Group Decision and Negotiation, 12: 217-41.

Tjosvold, D. (1998), "Making employee involvement work: Cooperative goals and controversy to reduce costs," Human Relations, 51: 201-14.

Tjosvold, D. (2008), "The conflict-positive organization: It depends on us," Journal of Organizational Behavior, 29: 19-28.

Tjosvold, D. and Weicker, D. (1993), "Cooperative and competitive networking by entrepreneurs: A critical incident study," Journal of Small Business Management, 31: 11-21.

Tjosvold, D., Hui, C., Ding, D. Z., and Hu, J. (2003), “Conflict values and team relationships: Conflict's contribution to team effectiveness and citizenship in China," Journal of Organizational Behavior, 24: 69-88.

Tsui, A, Egan, T., and O’Reilly, C. A. (1992), "Being different: Relational demography and organization attachment," Administrative Science Quarterly, 37: 549-79.

Tuckman, B. (1965), "Developmental sequence in small groups," Psychological Bulletin, 63: 384-99.

Turner, J. C. (1982), "Toward a cognitive redefinition of the social group," in Tajfel, H. (ed.), Social Identity and Intergroup Relations, Cambridge University Press, Cambridge: 15-40.

Tyler, T. R. and Blader, S. (2000), Cooperation in Groups: Procedural Justice, Social Identity, and Behavioral Engagement, Psychology Press, Philadelphia, PA.

Tyler, T. R. and Blader, S. L. (2003), "The group engagement model: Procedural justice, social identity, and cooperative behavior," Personality and Social Psychology Review, 7: 349-61.

Van Der Vegt, G. S. and Bunderson, J. S. (2005), "Learning and performance in multidisciplinary teams: The importance of collective team identification," Academy of Management Journal, 48: 532-47.

Van Der Vegt, G. S., Van De Vliert, E. and Oosterhof, A. (2003), “Informational dissimilarity and organizational citizenship behavior: The role of intra-team interdependence and team identification," Academy of Management Journal, 46: 715-27.

Van Dick, R. and Wagner, U. (2002), "Social identification among schoolteachers: Dimensions, foci, and correlates," European Journal of Work and Organizational Psychology, 11: 129-49.

Wann, D. L. (2006), "Understanding the positive social psychological benefits of sport team identification: The team identification-Social Psychological Health Model," Group Dynamics: Theory, Research, and Practice, 10: 272-96.

Wann, D. L. and Polk, J. (2007), "The positive relationship between sport team identification and belief in the trustworthiness of others," North American Journal of Psychology, 9: 251-6. 
Williams, K. Y. and O'Reilly, C. A. (1998), “Demography and diversity in organizations: A review of 40 years of research, Research in Organizational Behavior, 20: 77-140.

Wood, D., Harms, P. D. and Vazire, S. (2009), "Perceiver effects as projective tests: what your general perceptions of others says about you," unpublished manuscript.

Zaheer, A,, McEvily, B., and Perrone, V. (1998), "Does trust matter? Exploring the effects of interorganizational and interpersonal trust on performance," Organization Science, 9: 141-59.

$\langle\langle\langle\langle\langle\langle\rangle\rangle\rangle\rangle\rangle$

Guohong (Helen) Han (PhD, University of Illinois at UrbanaChampaign) is currently an Assistant Professor in Management in the College of Business Administration at the Youngstown State University. Her research interests are leadership, diversity, team development, and employee attitudes. She has published articles in the Academy of Management Best Conference Papers in 2006 and Journal of Organizational Behavior (in press). Guohong (Helen) Han is the corresponding author and can be contacted at: ghan@ysu.edu

P. D. Harms (PhD, University of Illinois at Urbana-Champaign) is currently a Post-doctoral Fellow at the Leadership Institute at the University of Nebraska-Lincoln. His current research focuses primarily on power motivation, workplace deviance, and the psychological experience of leadership. He has recently published articles in Journal of Applied Psychology, The Leadership Quarterly, Journal of Personality and Social Psychology, Intelligence, Personality and Social Psychology Bulletin, and a chapter in the Handbook of Psychological Measurement: A Multimethod Perspective. 